O-129 アロマスティックの簡易嗅覚検査への応用

○石丸 正

医）耳順会ひょうたん町耳鼻咽喉科医院

【はじめに】ソニーから発売されているアロマスティッ クは, 電子的に制御された 5 種類のにおいを発生させる ことのできる携帯型のデバイスで, コスメ用品として市 販されているものである。複数の種類のにおいを切り替 えて発生させることができるほか, スイッチを押したと き以外，においが拡散しないため，周囲を污染しない特 徵がある。今回，このアロマスティックを簡単な嗅覚 チェックに応用できないか検討した。【対象と方法】健常 者11名と当院に嗅覚障害を訴えて受診した患者20名であ る。これらの被験者に, T\&Tオルファークトメータで検 知域值, 認知域值を測定後, アロマスティックの 5 種の においをかいでもらい，においが有るか無いかを答えて もらった。なお, アロマスティックのにおいカートリッ ジは,「ビジネス」を用いた。においが有る場合は 1 点無 い場合は 0 点として, 全部わかれば 5 点満点として, 点数 化して評価した。なお, これらの被験者, 書面で説明と 同意を得たうえ, 研究に参加した。また, プロトコール は, 石川県医師会臨床研究倫理委員会で審査され承認さ れている。【結果】アロマスティックによる検査点数は, T\&Tオルファクトメータの検知, 認知域值と有意な関係 が認められ，簡易検査としてなら有用であることが分 かった。【考察】嗅覚障害の診断に嗅覚検査は必須だが, T\&Tオルファクトメータは一部の医療機関でしか実施 されておらず，アリナミンによる静脈性嗅覚検査が多用 されているが, 侵襲を伴ううえ, においが極めて強く, 最初に行う検査として適当ではない。また，香料などを ビンにいれ外来で嗅がせる方法も考えられるが, 部屋が においで污染される危険があり，使用しにくい。アロマ スティックをスクリーニング検查として応用するとこれ らの問題から逃れられる可能性がある。
O-130 T\&Tオルファクトメトリーにおけるにおい語 表の有用性の検討〜 B - SITとの相関性から〜

$\bigcirc$ 寺田 理沙 ${ }^{1}$, 端山 昌樹 ${ }^{2}$, 赤澤 仁司 ${ }^{2.3}$, 津田 武 ${ }^{2}$, 前田 陽平 ${ }^{2}$, 武田 和也 ${ }^{2,4}$, 小幡 翔 ${ }^{2}$, 中谷 彩香 ${ }^{2}$, 猪原 秀典 ${ }^{2}$

${ }^{1} \mathrm{JCHO}$ 大阪病院耳鼻咽喉科

${ }^{2}$ 大阪大学大学院医学系研究科耳鼻咽喉科 - 頭頸部外科学

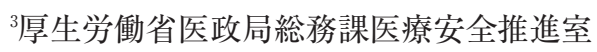

${ }^{4}$ 大阪市総合医療センター耳鼻咽喉科・頭頸部外科

【はじめに】嗅覚同定検査として本邦の保険診療で用い られている検査はT\&Tオルファクトメトリー（以下 T\&T）である。しかし，本検査は一般的には自由回答形 式であり，回答結果の正誤判定に迷う場合がある。そこ で，正誤判定を明確に行う為に，におい語表を用いた選 択回答形式が施行されているが，このにおい語表が嗅覚 同定能検査の評価ツールとして有用であるかは検討され ていない。一方，嗅覚同定検查として国際的に広く用 いられているものはUniversity of Pennsylvania Smell Identification Test (UPSIT) であるが, さらに多文化的 な 12 種類の嗅素に集約したBrief Smell Identification Test（B-SIT）がある。今回, T\&Tのにおい語表を用 いた選択回答形式と自由回答形式のそれぞれの認知域值 をB-SITスコアとの相関で比較し，におい語表の有用 性を検討した。

【対象と方法】対象症例は2017年9月から 2019年3月まで に大阪大学医学部附属病院の嗅覚外来を受診された 80 名 (男11名 女30名) で, T\& TとB-SITを施行した。そ のうち，2018年7月以降の受診された 39 名（男13名 女 26 名）はT\& $\&$ Tにおい語表を用いた選択回答形式で施 行した。統計学的検討にはJMP Pro13を使用した。相関 についてはSpearman相関係数を用いて算出し, $\mathrm{p}<0.05$ を有意とした。本研究は大阪大学医学部附属病院の倫理 委員会の承認を得て行われた（承認番号 $17087-2$ )。

【結果】 B-SITスコアとT\&T自由回答形式の認知域值の 相関はー0.46, B-SITスコアとT\&Tにおい語表回答形 式の認知域值の相関はー0.63であった。それぞれ相関は 示したが, T\&Tはにおい語表回答形式の方がより BSITと強い相関を示した。

【考察】におい語表を用いたT\& Tは嗅覚同定能評価とし て有用な検査であることが示唆された。 
O-131 Open Essenceによる嗅覚検査と認知機能との 関連〜十日町いきいき健康調査の解析〜

○佐々木崇暢, 新堀 香織, 堀井 新

新潟大学医学部耳鼻咽喉科・頭頸部外科

本学では十日町いきいき健康調査とよばれる健常高齢 者を対象とした学研究を行なっており, 昨年本学会で高 齢者の主観的嗅覚と客観的嗅覚に乘離がみられること, 認知機能低下に伴い嗅覚は低下する傾向がみられること を報告した。今回, Open Essence（OE）の各嗅素にお ける加齢性変化と, 認知機能との関連を検討したので報 告する。

対象は十日町いきいき健康調査に参加した65歳以上の 健常高齢者のうち, 鼻副鼻腔疾患の既往を除外した 456 名（男性：女性＝217：239）で, OEによる嗅覚検査と MMSE-Jによる認知機能を検討した。認知機能はMMSE の值により正常認知機能群（正常群 : MMSE $\geqq 28$ ), 軽 度認知機能低下群 $(\mathrm{MCI}$ 群 : $24 \leqq<28)$, 認知機能低下 群（低下群：<24）と分類した。嗅素毎の加齢性変化は, 墨汁 (65.6\%: $54.5 \%: 28.4 \%)$, 材木 $(72.2 \%: 55.8 \%$ : $46.9 \%)$, みかん $(45.7 \%: 28.6 \%: 28.4 \%)$, 練乳 (49.0\%: $35.3 \%: 27.2 \%)$ の 4 嗅素が年代間で有意差を認めた（p $<0.005$ )。嗅素と認知機能の検討では, 墨汁（正常群 : MCI群 : 低下群 $=60.6 \%: 48.2 \%: 38.5 \%)$, 材木 $(65.0 \%$ ： $57.6 \%: 38.5 \%)$, メントール (64.6\% : 54.5\% : 35.9\%), 練乳 (45.6\% : 32.5\% : 25.6\%) の4嗅素で有意差を認め た $(\mathrm{p}<0.005)$ 。認知機能により有意差のあった墨汁, 材 木, メントール, 練乳の嗅素の組み合わせとMMSE $<24$, $\geqq 24$ でROC曲線を描くと, 最もAUCが高值となったの は4嗅素の合計值 $(0 \sim 4)$ で $(\mathrm{AUC}=0.673)$, カットオ フ值を 2 に設定した場合, 感度 $69.5 \%$, 特異的 $59.0 \%$ と なった。

本検討により, OEの嗅素の中でも墨汁, 材木, みか ん, 練乳がより加龄に影響され, 墨汁, 材木, メントー ル, 練乳が認知機能に影響されることが示された。しか しながら認知機能低下のスクリーニングとしてはROC 曲線のAUCは $0.673 に$ 過ぎず, 十分な検出能力を持つと は言えなかった。

\section{O-132 頭部外傷後嗅覚障害の臨床的検討}

○山本小百合, 小河 孝夫, 清水 猛史

滋賀医科大学耳鼻咽喉科

【目的】外傷性嗅覚障害の嗅覚予後を明らかにすること。 【対象】2006年12月から 2017 年11月までに当科を受診 し, 外傷性嗅覚障害と診断された患者51例（男性33例, 女性18例）を対象にした。平均年齢は $42.2 \pm 19.7$ 歳（7～ 76 歳) であった。治療薬にはプレドニゾロン, ベタメ夕 ゾン点鼻液, メコバラミン, 当帰药薬散, 亜鉛などを使 用した。予後評価ができた症例は25例で, 平均観察期間

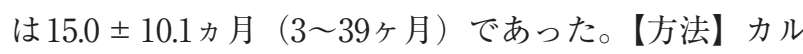
テ記載に基づく後ろ向き研究。受傷機転, 基準嗅覚検査 平均検知域值, 平均認知域值, 脳出血あるいは脳挫傷の 有無, 嗅力改善度について検討を行った。【結果】病悩期 間は平均 22.0 ケ月 \pm 42.5 カ 月（14日～23年）で，受傷機 転は交通事故34例（67\%), 転倒転落17例（33\%）であっ た。初診時重症度は正常 1 例 $(1.2 \%)$, 軽度 2 例 $(2.4 \%)$, 中等度 6 例 $(6.1 \%)$, 高度 12 例 $(12.2 \%)$, 脱失が 30 例 (30.6\%) であった。脳出血あるいは脳挫傷を認めたのは 9例（18\%）であった。予後評価ができた25例のうち, 日本鼻科学会嗅覚改善度判定基準で, 治癒率 $8 \%$ (2例), 改善率 $28 \%$ （7例）であった。脱失例が 15 例（60\%）と 多くを占め, 非脱失例と比較すると嗅覚予後は悪い傾向 にあった。脳出血あるいは脳挫傷の有無は嗅覚予後と関 連を認めなかった。基準嗅力検査平均検知域值, 認知域 值は,ともに受診後18か月まで改善傾向を認めた。【結 論】外傷性嗅覚障害には脱失例が多く, 治療による改善 率は $28 \%$ であった。受診後18か月まで嗅力の改善傾向を 認めた。 